Gut, 1989, 30, 387-390

\title{
Liver, biliary and pancreas
}

\section{Effect of glucocorticoid on liver regeneration after partial hepatectomy in the rat}

\author{
I TSUKAMOTO AND S KOJO
}

From Department of Food Science and Nutrition, Nara Women's University, Nara, Japan, and Laboratory of Food Chemistry and Nutrition, Department of Life and Health Sciences, Hyogo University of Teacher Education, Shimokume, Yashiro, Hyogo, Japan

\begin{abstract}
SUMmaRY The increase in activities of hepatic thymidylate synthetase (EC 2.1.1.45) and thymidine kinase (EC 2.7.1.21), which catalyse the formation of thymidylate through the de novo and salvage pathways, respectively, were significantly suppressed during liver regeneration in rats which were given glucocorticoids (hydrocortisone and dexamethasone) or indomethacin. These drugs also prevented the augment of hepatic DNA content in $24 \mathrm{~h}$ regenerating liver.
\end{abstract}

Liver regeneration after two-thirds partial hepatectomy (PH) has been used as an ideal model to investigate the regulatory mechanism of mammalian cell proliferation in vivo. Previous studies have established that various humoral factors regulate DNA synthesis in the regenerating liver.' As for the effect of glucocorticoids, Einhorn et $\mathrm{l}^{2}$ reported that cortisone diminished the DNA content in the regenerating liver and a similar conclusion was deduced by other workers..$^{3-6}$ On the contrary, Rixon and Whitfield reported that hydrocortisone did not prevent DNA synthesis in the regenerating liver.

We have recently showed that the activities of thymidylate synthetase (TS: EC 2.1.1.45) and thymidine kinase (TK: EC 2.7.1.21), which catalyse the formation of thymidylate through the de novo and salvage pathways, respectively, reflected closely the total amount of DNA synthesis and that these enzymes were rate determining in DNA synthesis. ${ }^{x-11}$ The present experiments were designated to determine the effect of glucocorticoids on the basis of the activities of TS and TK in liver regeneration. This approach allowed us direct comparison of these enzymatic activities with the amount of DNA synthesis as our previous reports. ${ }^{84} 1112$ The results show that the administration of glucocorticoids inhibits the increase of activities of TS and TK, resulting in the suppression of DNA synthesis in regenerating rat liver.

Address for correspondence: Dr lkuyo Tsukamoto, Department of Food Science and Nutrition, Nara Women's University, Nara, 630 Japan.

Accepted for publication 25 August 1988.

\section{Methods}

MATERIALS

( \pm )-L-Tetrahydrofolic acid was prepared by catalytic hydrogenation of folic acid according to the method of Huennekens et al. $.^{13}\left[5-{ }^{3} \mathrm{H}\right]-$ Deoxyuridine monophosphate $(10.6 \mathrm{Ci} / \mathrm{mmol})$ and $\left[6-{ }^{3} \mathrm{H}\right]$ thymidine $(21.0 \mathrm{Ci} / \mathrm{mmol})$ were purchased from Amersham (England). Dexamethasone and indomethacin were obtained from Sigma (USA). Hydrocortisone was from Nakarai Chemical Co (Japan). All other reagents were of analytical grade.

\section{ANIMALS AND TREATMENTS}

Male Wister rats (200-230 g) were used in this study. The animals were permitted free access to food (MF, Oriental Yeast Co, Osaka, Japan) and water at all times. Partial hepatectomy (PH) was performed under ether anaesthesia according to the procedure of Higgins and Anderson. ${ }^{14}$ Hydrocortisone in saline $(100 \mathrm{mg} / \mathrm{kg}$ ip) or dexamethasone in ethanol $(2 \mathrm{mg} / \mathrm{kg}$ ip) was injected one hour before PH or eight hours after PH. Indomethacin in ethanol (10 $\mathrm{mg} / \mathrm{kg}$ ip) was administered 30 minutes before $\mathrm{PH}$ or eight hours after $\mathrm{PH}$. Control animals received the same quantity of saline as did the experimental animals because no difference was observed in the effects of the vehicles.

\section{ANALYTICAL METHOD}

The rats were killed under ether anaesthesia at 24 hours after PH. Blood was withdrawn from the abdominal aorta and the liver was perfused in situ with saline. The calcium concentration in the plasma 
of these blood samples was measured utilising commercially available diagnostic kits (Calcium test Wako, Japan). The excised liver was homogenised with 4 volumes of $50 \mathrm{mM}$ Tris- $\mathrm{HCl}$ buffer, $\mathrm{pH} 7 \cdot 3$, containing $0.25 \mathrm{M}$ sucrose, $10 \mathrm{mM} \beta$-mercaptoethanol, $1 \mathrm{mM}$ phenylmethylsulphonyl fluoride and $1 \mathrm{mM}$ EDTA. The DNA content of liver was measured by the diphenylamine reaction ${ }^{15}$ after extraction with trichloroacetic acid according to the procedure of Schneider. ${ }^{16}$ Protein was determined by the method of Lowry et $a l^{17}$ using bovine serum albumin as standard. The activities of TS and TK were determined as described previously ${ }^{x / x}$ and expressed as pmols of product formed $/ \mathrm{min} / \mathrm{mg}$ protein at $37^{\circ} \mathrm{C}$. Statistical analyses of data were by Student's $t$ test.

\section{Results}

EFFECTS OF GLUCOCORTICOIDS ON $24 \mathrm{H}$

REGENERATING RAT LIVER

After PH the activities of TS and TK started increasing at about 12th hour and peaked at 24-48 $\mathrm{h}$ after $\mathrm{PH}^{\times{ }^{\times 14}}$ In the normal liver (taken just after $\mathrm{PH}$ and resting in $G_{0}$ state), the activities of these enzymes were very low (Table) as in sham operated liver. When hydrocortisone $(100 \mathrm{mg} / \mathrm{kg}$ ip) was injected one hour before $\mathrm{PH}$, the TS activity in $24 \mathrm{~h}$ regenerating rat liver was increased considerably compared with the normal value but decreased to $42 \cdot 3 \%$ of the control (hepatectomised) as shown in the Table. The TK activity of these rats also increased 2.56 times of the normal but decreased to $21.6 \%$ of the control (hepatectomised) (Table). Dexamethasone $(2 \mathrm{mg} / \mathrm{kg}$ ip) given one hour before $\mathrm{PH}$ suppressed TS activity at $24 \mathrm{~h}$ after $\mathrm{PH}$ to about one third of the control (hepatectomised). Thymidine kinase activity diminished to $27 \cdot 3 \%$ of the control (hepatectomised) value by the injection of dexamethasone (Table). These TS and TK activities were again higher than the corresponding level of the normal values.

The hepatic DNA content at $24 \mathrm{~h}$ after $\mathrm{PH}$ in the control animals increased significantly compared with that just after PH (Table). In the rat pretreated with hydrocortisone or dexamethasone, the liver DNA content was significantly lower than that of the control (hepatectomised). The decrease of DNA content was in concert with the low enzymatic activities of TS and.TK (Table).

The plasma calcium concentration of rats treated with the glucocorticoids was lower than that of the control at $24 \mathrm{~h}$ after $\mathrm{PH}$ (Table).

When dexamethasone was administered to rats at eight hours after PH similar effects were observed on the activities of TS and TK as well as liver DNA content. Plasma calcium concentration was also depressed by the treatment.

EFFECTS OF INDOMETHACIN ON 24 H

REGENERATING RAT LIVER

Rats were treated with indomethacin $(10 \mathrm{mg} / \mathrm{kg}$ ip) 30 minutes before $\mathrm{PH}$ and the regenerative responses were evaluated in $24 \mathrm{~h}$ regenerating liver. Activities of TS and TK raised significantly compared with those of the normal but considerably lower than those of the control rats. These were comparable with the values of the dexamethasone treated group. The quantity of liver DNA was diminished by the administration of indomethacin compared with the control group. Indomethacin was found to decrease plasma calcium level as hydrocortisone and dexamethasone. This was consistent with the literature. ${ }^{20}$

When indomethacin was administered at eight hours after PH, similar effects on DNA synthetic responses and plasma calcium concentration were observed as shown in the Table.

Table Effect of hydrocortisone, dexamethasone and indomethacin on the activities of TS and TK, DNA content, and plasma calcium level at 24 h after partial hepatectomy $(P H)$

\begin{tabular}{|c|c|c|c|c|c|}
\hline $\begin{array}{l}\text { Treatment } \\
\text { [injected time: } \\
\text { h after } P H]\end{array}$ & $\begin{array}{l}\text { Rats } \\
(n)\end{array}$ & $\begin{array}{l}\text { TS } \\
\text { (pmol/mg protein/min) }\end{array}$ & $\begin{array}{l}\text { TK } \\
\text { (pmol/mg protein } / \mathrm{min})\end{array}$ & $\begin{array}{l}\text { Liver DNA } \\
(m g)\end{array}$ & $\begin{array}{l}\text { Plasma calcium } \\
(\mathrm{mg} / 100 \mathrm{ml})\end{array}$ \\
\hline Control (PH only) & 17 & $67 \cdot 53(6 \cdot 10)$ & $220 \cdot 94(26 \cdot 22)$ & $6.99(0.24)$ & $9 \cdot 45(0 \cdot 22)$ \\
\hline Hydrocortisone [-1] & 6 & $28.57(5.47)^{\dagger}$ & $47.83(8.43)^{\dagger}$ & $6.02(0.31)^{*}$ & $7.75(0.69)^{*}$ \\
\hline Dexamethasone $[-1]$ & 10 & $22.33(3.40) \dagger$ & $60.25 \quad(8.45)^{\dagger}$ & $5.94(0.39)^{*}$ & $7.84(0.36)^{*}$ \\
\hline Dexamethasone $[8]$ & 6 & $19 \cdot 61(1.09)^{\dagger}$ & $77.11 \quad(4.08)^{\dagger}$ & $5.78(0.55)^{*}$ & $8.42(0.34)^{*}$ \\
\hline Indomethacin $[-0 \cdot 5]$ & 13 & $27.51(2.91) \dagger$ & $68.29(13.90)$ & $6.03(0.27)^{*}$ & $7.73(0 \cdot 22)^{*}$ \\
\hline Indomethacin [8] & 4 & $21 \cdot 14(3.66)^{\dagger}$ & $73.38(24.67)^{+}$ & $6.06(0.09)^{*}$ & $8.37(0.35)^{*}$ \\
\hline Normal (just after PH) & 20) & $9.91(0.99)^{\dagger}$ & $18.69(1.38)^{\dagger}$ & $5.46(0.31)^{\dagger}$ & $10 .(09(0.31)$ \\
\hline
\end{tabular}

Hydrocortisone (100 $\mathrm{mg} / \mathrm{kg}$ ip) was injected one hour before PH. Dexamethasone ( $2 \mathrm{mg} / \mathrm{kg}$ ip) was injected one hour before or eight hours after PH. Indomethacin $(10 \mathrm{mg} / \mathrm{kg}$ ip) was administered 30 minutes before or eight hours after PH. At $24 \mathrm{~h}$ after PH, the activities of TS and TK. DNA content and plasma calcium level were determined as described in the Methods section. Values are expressed as mean (SE).

$*+$ indicate significant differences from the control $(* . p<0 \cdot 05: \div \mathrm{p}<0 \cdot(01)$ 


\section{Discussion}

The results of this study showed that hydrocortisone and dexamethasone prevented the rise in the activities of TS and TK which are rate determining enzymes in DNA synthesis, ${ }^{,-11}$, with a concomitant decline in DNA content in the regenerating rat liver. These observations are compatible with the reports that showed diminished DNA content by cortisone, ${ }^{26}$ and with the results that described the decreased incorporation of labelled thymidine into DNA by glucocorticoids. ${ }^{3.5}$

The fact that the glucocorticoids inhibited DNA synthesis during liver regeneration suggests that one or more of the arachidonate derivatives are involved in the early process of regulation of TS and TK. Hydrocortisone and dexamethasone are known to prevent the release of arachidonic acid from phospholipids by promoting the synthesis of a peptide inhibitor of phospholipase. ${ }^{212}$ The involvement of the product(s) of arachidonate cascade system in the regulation of TS and TK may be supported by our observation that indomethacin, a potent inhibitor of fatty acid cyclooxygenase, ${ }^{23}$ showed similar effects to the glucocorticoids as shown in the Table. The ability of indomethacin to block DNA synthesis estimated by incorporation of $\left[{ }^{3} \mathrm{H}\right]$ thymidine is shown in the literature ${ }^{72124}$ and these reports coincide with our results. MacManus and Braceland ${ }^{20}$ suggested prostaglandin $\mathrm{E}_{2}$ and $\mathrm{F}_{2 \alpha}$, while Kanzaki et al s. $^{5}$ proposed thromboxane (not prostaglandin $\mathrm{F}_{2 \alpha}$ ) as a regulator of liver regeneration. It remains to be explored what arachidonate derivatives control liver regeneration.

In liver regeneration after $\mathrm{PH}$ the first transition of the hepatic cell from $G_{0}$ to $G_{1}$ phase seems to take place within four hours, during which $c$-fos ${ }^{26}$ and c-myc ${ }^{27}$ oncogenes are expressed. ${ }^{2 x}$ The second signalling form $G_{1}$ to $S$ phase is assumed to occur at 10-12 hours. ${ }^{.}$This is supported by the time dependence of $\alpha_{1}$-blockers ${ }^{x}$ to prevent the induction of TS and TK, which are S-phase specific enzymes. ${ }^{2 x}$ Glucocorticoids and indomethacin prevented the induction of TS and TK when applied before PH as shown above. When these drugs were administered at as late as eight hours after $\mathrm{PH}$, quantitatively similar effects were observed on $24 \mathrm{~h}$ regenerating liver (Table). Therefore, these drugs may interfere with the events involved in $\mathrm{S}$ phase and/or the second transition of hepatic cells into $\mathrm{S}$ phase, just like $\alpha_{1}$-blockers." Further studies are needed to elucidate the relationship among signals caused by catecholamine, calcium ${ }^{412}$ and arachidonate derivatives in the regulation of DNA synthesis in liver regeneration.

Hydrocortisone, dexamethasone and indomethacin lowered plasma calcium level in partially hepa- tectomised rats as shown in the Table. The effect of indomethacin was reported by MacManus and Braceland.." Prolonged hypocalcaemia (more than $48 \mathrm{~h}$ ) induced by thyroparathyroidectomy prevented the rise in TS and TK activities in $24 \mathrm{~h}$ regenerating rat liver but hypocalcaemic condition for $24 \mathrm{~h}$ did not affect the induction of TK. ${ }^{9}$ Because the duration and the degree of decrease of plasma calcium in the present experiment are less than those caused by thyroparathyroidectomy, the inhibition of TS and TK by the drugs cannot be ascribed only to decreased calcium ion. Rather, the direct effect on the hepatic functions - for example, prostaglandin synthesis, calcium mobilisation and calcium entry, may explain the inhibitory action of these chemicals on DNA synthesis in rat liver regeneration.

Finally it is worthwhile to note that care must be taken in the administration of glucocorticoids and indomethacin to patients with a liver disease, because these drugs possibly interfere with liver regeneration and are potentially hepatotoxic.

\section{References}

1 Leffert HL, Koch KS, Moran T, Rubalcava B. Hormonal control of rat liver regeneration. Gastroenterology 1979; 76: $1470-82$.

2 Einhorn SL, Hinschberg E, Gcllhorn A. Effects of cortisone on regenerating rat liver. J Gen Physiol 1954; 37: 559-76.

3 Guzek JW. Effect of adrenocorticotrophic hormone and cortisone on the uptake of tritiated thymidine by regenerating liver tissue in the white rat. Nature 1964; 201: 930-1.

4 Raab KH, Webb TE. Inhibition of DNA synthesis in regenerating rat liver by hydrocortisone. Experientia 1969; 25: 1240-2.

5 Rizzo AJ, Heilpern P, Webb TE. Temporal changes in DNA and RNA synthesis in the regenerating liver of hydrocortisone-treated rats. Cancer Res 1971; 31: 876-81.

6 Castellano TJ, Schiffman RL, Jacob MC, Locb JN. Suppression of liver cell proliferation by glucocorticoid hormone: A comparison of normally growing and regenerating tissue in the immature rat. Endocrinology 1978; 102: 1107-12.

7 Rixon RH. Whitfield JF. An carly mitosis-determining event in regenerating rat liver and its possible mediation by prostaglandins or thromboxane. J Cell Physiol 1982; 113: $281-8$.

8 Nakata R. Tsukamoto I, Nanme M, Makino S, Miyoshi $M$, Kojo S. $\alpha$-Adrenergic regulation of the activity of thymidylate synthetase and thymidine kinase during liver regeneration after partial hepatectomy. Eur $J$ Pharmacol 1985; 114: 355-60.

9 Nakatata R, Tsukamoto I, Miyoshi M, Kojo S. Effect of thyroparathyroidectomy on the activities of thymidylate synthetase and thymidine kinase during liver regeneration after partial hepatectomy. Clin Sci 1986: 72: 455-61. 
10 Tsukamoto I, Kojo S. One evidence supporting that thymidylate synthetase and thymidine kinase are the rate-determining enzymes of DNA synthesis in regenerating rat liver. Chem Lett 1987: 2313-6.

11 Nakata R. Tsukamoto I, Miyoshi M, Kojo S. Liver regeneration in streptozotocin-diabetic rats. Biochem Pharmacol 1986; 35: 865-6.

12 Tsukamoto I, Kojo S. Effect of calcium channel blockers and trifluoperazine on rat liver regeneration. Eur $J$ Pharmacol 1987; 144: 159-62.

13 Huennekens FM, Mathews CK, Scrimgeour KG. Preparation and properties of tetrahydrofolic acid. Methods Enzymol 1966; 6: 802-5.

14 Higgins GM, Anderson RM. Experimental pathology of the liver: restoration of the liver of the white rat following partial surgical removal. Arch Pathol 1931; 12: 186-202.

15 Burton K. A study of the conditions and mechanism of the diphenylamine reaction for the colorimetric estimation of deoxyribonucleic acid. Biochem J 1956; 62: 315-22.

16 Schneider WC. Determination of nucleic acids in tissues by pentose analysis. Methods Enzymol 1957; 3: 680-4.

17 Lowry OH, Rosebrough NJ, Farr AL, Randall RJ. Protein measurement with the folin phenol reagent. J Biol Chem 1951; 193: 265-75.

18 Nakata R, Tsukamoto I, Miyoshi M, Kojo S. Liver regeneration after carbon tetrachloride intoxication in the rat. Biochem Pharmacol 1985; 34: 586-8.

19 Labow R, Maley GF, Malcy F. The effect of methotrexate on enzymes induced following partial hepatectomy. Cancer Res 1969; 29: 366-72.
20 MacManus JP, Braceland BM. A connection between the production of prostaglandins during liver regeneration and DNA synthetic response. Prostaglandins 1976; 11: 609-20.

21 Danon A, Assouline G. Inhibition of prostaglandin biosynthesis by corticosteroids requires RNA and protein synthesis. Nature 1978; 273: 552-4.

22 Flower RJ, Blackwell GJ. Anti-inflammatory steroids induce biosynthesis of a phospholipase $A_{2}$ inhibitor which prevents prostaglandin generation. Nature 1979; 278: $456-9$.

23 Shen TY, Winter CA. Chemical and biological studies on indomethacin, sulinduc and their analogues. $A d v$ Drug Res 1977; 12: 90-245.

24 McNeil GE, Chen TS, Leevy CM. Reversal of ethanol and indomethacin-induced suppression of hepatic DNA synthesis by 16,16 -dimethyl-prostaglandin $E_{2}$. Hepatology 1985; 5: 43-6.

25 Kanzaki Y, Mahmud I, Asanagi M, Fukui N, Miura Y. Thomboxane as possible trigger of liver regencration. Cell Mol Biol 1979; 25: 147-52.

26 Kruijer W, Skelly H, Botteri F, van der Putten H, Barber JR, Verma IM, Leffert HL. Proto-oncogene expression in regenerating liver is stimulated in cultures of primary adult rat hepatocytes. $J$ Biol Chem 1986; 261: 7929-33.

27 Makino R, Hayashi K, Sugimura T. c-myc transcript is induced in rat liver at a very early stage of regeneration or by cycloheximide treatment. Nature 1984; 310: 697-8.

28 Denhardt DT, Edwards DR, Parfett CLJ. Gene expression during the mammalian cell cycle. Biochim Biophys Acta 1986; 865: 83-125. 